\title{
Stable partnerships as a resource for a modern educational organization
}

\author{
Ekaterina Vezetiu*, and Ekaterina Vovk \\ V.I. Vernadsky Crimean Federal University, Prospekt Vernadskogo, 4, 295007 Simferopol, Russia
}

\begin{abstract}
This study examines the phenomenon of the formation of stable partnerships as the main resource of a modern educational organization, aimed at helping students acquire not only disciplinary competencies but also a system of moral and ethical values, social and creative abilities, psychological and social adaptability in the socio-cultural space, within whose framework they develop and shape as individuals and professionals. It also examines the essence and process of building such relationships in the higher education system. The study deals with comprehending the role of educational activity in the modern socio-cultural environment, and with revealing the theoretical foundations of the formation of joint activities in the context of an interdisciplinary and multifunctional approach. The main research method here is the method of questioning students from one of the leading universities of the Republic of Crimea: Federal State Autonomous Educational Institution of Higher Education "Crimean Federal University named after V.I. Vernadsky" on the topic "Revealing the role of joint activities and partnerships as a key resource of a modern progressive educational organization." Among the respondents there are representatives of various areas of training, different levels of education, and forms of education. It is important to note that not only the interpersonal partnership of students is assessed directly in the course of the educational process, but also their opinion regarding the existing external partnerships of the educational institution with other organizations that provide educational services to one degree or another. The study also considers pedagogical partnerships and partnerships between teacher and student. The research results are fully reflected and presented in the form of a complex analytical conclusion, which is of particular interest for further statistical, social and pedagogical research on this topic.
\end{abstract}

\section{Introduction}

There is a wide variety of reasons and circumstances that led to the need of modernizing and transforming existing stable public institutions within the framework of higher professional education. It is important to understand that, despite the existing array of research studies, it is rather difficult to determine the forms, methods and technologies of future educational institutions that will replace the traditional ones $[5,13]$. Changes in

*Corresponding author: viza_1986@ukr.net 
education, dictated by trends in the outside world, are being actively investigated by various scientists in the context of polyfunctionality and multi-levelness.

At the same time, an active discussion is underway in the scientific community of teachers regarding the deformation of education, its principles and qualitative changes in its structure, which have affected both educational legislation, and, in fact, the structure of educational organizations, educational programs, funding in education, personnel, technical, digital equipment. educational process, methods of organizing and managing this process.

Thus, it emphasizes the change in the role of higher education not only in the social, but also in the personal and psychological plans, which dictates new rules for managers, teachers and students. At the same time, it becomes necessary to form a structure of a new type of relations between various subjects of educational interactions, which should consist in mutually beneficial replenishment of each other's bases. The subjects of the educational process must learn to interact in the most effective and productive form, which will maximize the effect received from the educational organization.

\section{Materials and Methods}

The study was based on a questionnaire survey of students and graduates (both carrying out professional activities in parallel with studying at the university, and carrying them out after directly completing training) of various areas of training and forms of training, in which a total of more than 200 people took part, subjects of educational and training activities of one of the leading universities of the Republic of Crimea: Federal State Autonomous Educational Institution of Higher Education "Crimean Federal University named after V.I. Vernadskiy"

The survey was carried out in several stages, whose purpose was to identify existing gaps in the application of the method aimed at forming a stable partnership between the university, the teaching staff, students and external organizations, which will make it possible to formulate in the future the newest concepts of the strategy for the implementation of such methods in certain areas of activity of universities in the Republic of Crimea and Russia. In the course of the study, fundamentally new types of partnership interaction between various subjects of the educational space were identified.

The purpose of this study was to identify the most pressing problems in the application of the method of stable partnership on the basis of the Federal State Autonomous Educational Institution of Higher Education "Crimean Federal University named after V.I. Vernadskiy" In addition, another goal can be considered as the identification of the most attractive way for modern students to organize partnerships and compile the efforts of the university, teachers, external organizations and the students themselves.

\section{Results and Discussion}

Joint partnership activity is one of the most effective types of productive interaction of subjects of any existing field of activity. It allows you to minimize risks by attracting a large number of people to the implementation of a particular idea, using material, psychological and other resources to achieve a common goal.

Such interaction is especially active within the framework of the project activities of students, which are aimed at achieving a single common goal of project activities, as well as the formation of a project competent group capable of carrying out tasks of varying complexity, gradually increasing the load and expanding the range of influence of design skills. It is important to remember that the formation of the concept of partnership requires 
preliminary assessment and analysis, which should be taken into account when building the primary concept of interaction between the subjects of the educational process $[1,7]$.

The authors would like to draw the attention of the audience to the variety of options for such a partnership within an educational institution. So, in our opinion, there are the following types of stable partnerships that affect the quality of educational services and the quality of education in general:

1. Student - student.

With this type of partnership, students are forced (in order to carry out a project task that is mandatory for a specific group or of their own free will) to interact with each other to perform project or any other collective activity. At the same time, students establish partnerships within the group, based on the tasks, goals, methods and ways to achieve the goal of joint activities. In addition, partnerships can be long-term in this case. So, for example, at the beginning of their studies at the university, students can form interest groups and work exclusively in them in accordance with their desires and abilities. Such groups are often strong enough to work most harmoniously and productively. Speaking about short-term partnerships, it can be noted that they can also be effective in case of correct distribution of the forces of all students (when more capable students are paired with less capable ones, thereby harmonizing and balancing the efforts of all members of the group).

2. Student - teacher.

In this case, the partners are a teacher-tutor or a curator and a student, towards whom the pedagogical and educational influence of the teacher is directed. In such partnerships, it is important for the student to take his/her own position and form his/her own concept of interaction with a more experienced and accomplished specialist. The teacher, on the other hand, needs to pay attention to the realization of the student's abilities, instead of concentrating on the actual fulfillment of the goal of interaction. It is important to understand that the teacher places himself/herself on the same step with the student, while the student rises one step higher.

3. Teacher - educational institution.

With this type of interaction, all kinds of partnership elements are taken into account, which are aimed not so much at mutual benefit as at achieving a single result: providing the labor market with a capable, hardworking and responsible professional who knows how to apply the skills of organization and self-organization, and is also aware of the need for stable partnership in professional activities.

4. Organization - organization.

In this type of case, the educational institution is in partnership with any organization that provides additional educational services related to the provision of jobs for internship for graduates and students of the university. At the same time, the university, in turn, sends qualified personnel specifically to this organization, which supports the mutually beneficial exchange of "resources".

Thus, it is necessary to understand that the essence of partnership lies not only in mutual benefit, but also in the achievement of a socially significant ideal by all existing efforts. To study this phenomenon, we carried out an analytical study aimed at identifying the most effective way of productive interaction within the educational organization. In addition, it is important to note that respondents belong to different areas of training and study in different forms (full-time, part-time and full-time/part-time), which minimizes the risks of bias for one or another group of respondents.

In the course of this study, a questionnaire was conducted on the topic "Stable partnerships within the framework of higher professional education: the formation of competencies for productive collective interaction of students, university and teachers" 
among students and graduates of the Federal State Autonomous Educational Institution of Higher Education "Crimean Federal University named after V.I. Vernadskiy"

The respondents were 150 students and 55 graduates carrying out professional activities in their specialty (either in parallel with their studies, or after graduation). At the same time, the questionnaire questions were aimed simultaneously at both groups of participants in the educational process. In this regard, the study and its results can be considered complex, expedient, relevant and aimed at solving existing educational problems.

The results of the survey showed that $55 \%$ of the surveyed students consider partnership to be an effective method of implementing joint activities within the educational process; $70 \%$ of graduates claim that they apply the skills acquired during such interaction at the stage of professional training directly in their professional activities; $63.4 \%$ of the total number of respondents come to the conclusion that it is necessary to introduce a greater number of collective tasks of a practical nature into the pedagogical practice of organizing the educational process within the framework of the professional training of specialists of different levels. At the same time, $43.3 \%$ of students believe that collective activity is largely inferior to the individual one, since the result does not depend on one person, but on the situations created by the team, on the degree of effort by each member of the partnership, as well as on the level of skills of each. This group of respondents argues that individual activities are much more efficient in terms of implementing the original idea in the form in which it was initially presented. Of course, we should not forget about the $1.7 \%$ of respondents who refrained from answering, which indicates insufficient experience or lack of interest in questioning on the part of individual respondents.

$23.5 \%$ of graduates believe that collective activity reduces the time it takes to complete professional tasks, which has a direct impact on the positioning of employees in the company, on their self-actualization and wages. $6.5 \%$ of graduates refrained from answering.

$36.6 \%$ of the total number of respondents, nevertheless, are convinced that the content of programs for the practical application of skills and abilities acquired in the course of vocational training should be individual and not collectively oriented, since this does not correspond to the main modern trends in the field of education. Indeed, today the world community is widely discussing the position of centralizing education around the student, who is the core of educational activity, its goal and result. Thus, we can conclude that partnership is a complex system that is not suitable for all students and is aimed at developing a variety of multifunctional competencies.

Within the framework of the same study, we assessed the degree of student satisfaction with the technologies of partner productive interaction of educational activities within the framework of vocational training at the Federal State Autonomous Educational Institution of Higher Education "Crimean Federal University named after V.I. Vernadsky", which allowed us to outline a certain range of problems to be solved in the field of managerial and organizational activities of this institution. The results of this survey can be found in Table 1.

Table 1. Satisfaction of students with the formed concept of stable partnerships within the framework of educational, organizational and administrative activities of the university (\%)

\begin{tabular}{|l|l|l|l|l|}
\hline & $\begin{array}{l}\text { Partial } \\
\text { satisfaction }\end{array}$ & $\begin{array}{l}\text { Absolute } \\
\text { satisfaction }\end{array}$ & $\begin{array}{l}\text { Partial } \\
\text { dissatisfaction }\end{array}$ & $\begin{array}{l}\text { Absolute } \\
\text { dissatisfaction }\end{array}$ \\
\hline $\begin{array}{l}\text { The quality of partnership with } \\
\text { teachers }\end{array}$ & 36.9 & 46.4 & 11.1 & 5.6 \\
\hline $\begin{array}{l}\text { The quality of partnership with } \\
\text { the university (management } \\
\text { structure, financial structure, } \\
\text { personnel structure) }\end{array}$ & 27.7 & 14.3 & 29.6 & 28.4 \\
\hline
\end{tabular}


Table 1. Continued

\begin{tabular}{|l|l|l|l|l|}
\hline $\begin{array}{l}\text { The quality of partnership with } \\
\text { fellow student } / \text { other } \\
\text { representatives of the student } \\
\text { body quality of individual }\end{array}$ & 76.8 & 16.5 & 13.2 & 7.1 \\
\hline $\begin{array}{l}\text { The qua (as opposed to } \\
\text { activities partnership) } \\
\text { collective, partnership }\end{array}$ & 59.3 & 21.9 & 14.6 & 4.2 \\
\hline $\begin{array}{l}\text { The quality of partners } \\
\text { between leading teachers and the } \\
\text { university quality of partnerships }\end{array}$ & 38.7 & 32.9 & 13.9 & 14.5 \\
\hline $\begin{array}{l}\text { The quate } \\
\text { between the university and other } \\
\text { organizations }\end{array}$ & & 13.3 & 6.4 & 15.5 \\
\hline $\begin{array}{l}\text { The quality of partnerships } \\
\text { among teachers }\end{array}$ & 64.8 & & & \\
\hline
\end{tabular}

Based on the data presented in the table, we can conclude that the concepts of building partnerships between students and other students demonstrated the best result - 79.6\%; those of teachers with the university $-81.2 \%$; and those teachers within the team $-79.1 \%$. At the same time, in the course of the study, individual activities became priority $-88.8 \%$. Other types of partnerships are less popular, despite their seemingly greatest possible efficiency. Based on this, it can be noted that the goals of education today are dictated by students, they also partially choose the methods and technologies of educational activities.

In the near future, a complete transformation of the educational process is possible, in which the role of the teacher will become not mentoring, but, rather, that of being partner and tutor. At the same time, as of today students are already dictating their own requirements, calling for the educational process to be organized in the most comfortable form for them.

It is important to understand that partnership at all levels of education can and should be present, since it is this partnership that forms the potential for productive collective interaction of students, educational institutions, teachers and additional organizations that carry out educational activities. It is necessary to correctly and harmoniously arrange individual and collective activities so that the professional training of a future specialist is carried out in all possible directions, and not specifically within the framework of one concept.

\section{Conclusions}

In conclusion, we would like to note that the formation of a complex system of partnership relations should be based on extensive theoretical and practical material of a fundamental and applied nature, which will allow the organizer of educational activities to implement the most positive scenario for the development of educational activities and relationships between subjects within its framework.

It should be borne in mind that modern students are mainly aimed at self fulfillment, rather than at fulfilling a social order. That is, education for them is an end in itself, which forms not only their competence, but also self-awareness, self-sufficiency, and independence.

At the same time, any organizer of partnership relations needs to understand the theory of partnership, interpersonal communication, and have the skills of psychology and sociology. It is important to understand that partnership is a model of real social interaction that can influence the formation of new concepts for the younger generation, and can also become a starting point for their global socialization. In this regard, it is necessary to pay attention to the conduct of regular sociological and pedagogical research related to the 
introduction of mechanisms and methods of effective productive partnership aimed at improving the social relations of the subjects of the educational process.

It is essential to study the mechanisms, means, technologies, techniques and ways of influencing and organizing partnerships not only in the student environment, but also in the pedagogical and professional one. This is critical, first of all, for the formation of a favorable image of the educational organization and the improvement of the qualifications of its employees.

\section{References}

1. A. Apokin, M. Yudkevich, Economic Issues, 6, 98 (2008)

2. G. Bazarova, Systemic business education helps a person to use their experience, look inside themselves and become wiser, 4, 7 (2003)

3. L. Boone, D. Kurtz, Modern marketing (2005)

4. S. Vargo, R. Lash, Russian Management Journal, 4(2), 73 (2006)

5. G.B. Golub, E.Ya. Kogan, V.A. Prudnikova, Education Issues, 2, 20 (2007)

6. V. Golubkin, S. Kalendzhyan, L. Kleeva, Economic Issues, 7, 129 (2006)

7. J. Gordon, Marketing partnerships (2001)

8. L. Grebnev, Economic Issues, 3, 20 (2005)

9. A. Grudzinsky, Socis, 4, 88 (2003)

10. D. Egan, Marketing relationships, Analysis of marketing strategies based on relationships (2008)

11. L. Ionin, V. Kultygin, G. Osipov, History of sociology in Western Europe and the USA (2001)

12. G. Klyucharev, E. Pakhomova, Education Issues, 2, 117 (2007)

13. M. Kolchugina, World economy and international relations, 12, 42 (2003)

14. G. Konstantinov, S. Filonovich, Questions of education, 4, 106 (2005)

15. S. Krasavchenko, Personnel management, 4, 12 (2003) 